\title{
LEGAL ANALYSIS OF GOVERNMENT POLICY ON LARGE SCALE SOCIAL RESTRICTIONS IN HANDLING COVID-19
}

\author{
Ratna Desinta Mega Kumala \\ Research Center for Access to Justice, Semarang, Indonesia \\ Email: ratnadesintamegakumala@gmail.com
}

\begin{abstract}
Corona Virus Disease 2019(COVID-19) has been declared by the World Health Organization (WHO) as a pandemic so prevention efforts need to be made to avoid an increase in cases. In the context of prevention efforts carried out the implementation of health quarantine as regulated in Act Number 6 of 2018 concerning Health Quarantine. The implementation of health quarantine is a joint responsibility of the Central Government and Regional Governments as a form of protection of public health from diseases and / or public health risk factors that have the potential to cause public health emergencies. Health quarantine is carried out through disease observation activities and public health risk factors for transportation, people, goods, and or the environment, as well as responses to public health emergencies in the form of Health quarantine measures. One of the acts of health quarantine is in the form of largescale social restrictions. The spread of Corona Virus Disease 2019 (COVID-19) in Indonesia is now increasing and expanding across regions and across countries accompanied by the number of cases and / or the number of deaths. The increase has an impact on political, economic, social, cultural, defense and security aspects, as well as the welfare of the people in Indonesia, so it is necessary to accelerate the handling of Corona Virus Disease 2019 (COVID-19) in the form of large-scale social restrictions in order to reduce the spread of Corona Virus Disease 2019 (COVID-19) is expanding.
\end{abstract}

Keywords: Large Scale Social Restriction, PSBB, Covid-19, Government Policy

The Indonesian Journal of International Clinical Legal Education ISSN 2721-8368

DOI: 10.15294/ijicle.v2i2.38326

(C) 2020 Authors. This work is licensed under a Creative Commons

Attribution-ShareAlike 4.o International License. All writings

published in this journal are personal views of the authors and do not

represent the views of this journal and the author's affiliated institutions.

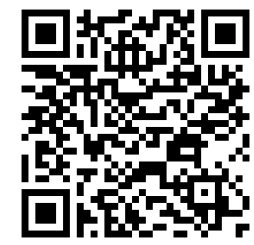


Kumala

\section{INTRODUCTION}

Recently from the beginning of this year, coronavirus become an issue of emergency global health. Started found the death case in Wuhan, China until already spread out to almost all over the world. The coronavirus novel (2019-nCoV) is a new type of virus that has never been identified before in humans, it is a large family of viruses that cause diseases ranging from mild to severe symptoms. There were two types of virus outbreaks before coronavirus which are Middle East Respiratory Syndrome (MERS-CoV) and Severe Acute Respiratory Syndrome (SARS-CoV).

Coronavirus is zoonosis (transmitted between animals and humans). Research says that SARS-CoV is transmitted from civet cats to humans and MERS-CoV from camels to humans. Some coronaviruses are known to circulate in animals but have not been proven to infect humans. Clinical manifestations usually appear within 2 days to 14 days after exposure. Common signs and symptoms of coronavirus infection include acute respiratory distress symptoms such as fever, coughing and shortness of breath. In severe cases it can cause pneumonia, acute respiratory syndrome, kidney failure, and even death. The 2019-20 coronavirus pandemic was confirmed to have spread to Indonesia on 2 March 2020, when a dance instructor and her mother were infected from a Japanese national. ${ }^{12}$ Because at that time, many policies and strategies were made within the framework of significant displacement and death from this disease. One of them was the issuance of Government Regulation No. 21 of 2020 concerning Large-Scale Social Restrictions in the context of acceleration of the Handling of the 2019 Corona Virus Disease (Covid-19). However, all policies and strategies carried out by our government have not escaped the various responses and perceptions given by the community. ${ }^{3}$ With the policies and regulations that have been issued, the government hopes to slow the process of spreading the corona virus in Indonesia.

1 "First coronavirus cases confirmed in Indonesia amid fears nation is ill-prepared for an outbreak", the Guardian. 8 March 2020. Accessed 8 April 2020.

2 Limited, Bangkok Post Public Company. "Indonesia confirms first cases of coronavirus". www.bangkokpost.com. Accessed 8 April 2020

3 Ellyvon Pranita, "Berbagai Respon Rakyat Untuk PemerintahTerkait Penanganan Covid-19” (https://www.kompas.com/sains/read/2020/04/02/100200323/berbagairespons-rakyat-untuk-pemerintah-terkait-penanganan-covid-19, Accessed 8 April 2020). 


\section{CORONA VIRUS, LOCKDOWN ISSUES, AND LEGAL IMPACT: SOME RECENT CASES IN INDONESIA}

Corona virus is a large family of viruses that cause disease in humans and animals. In humans it usually causes respiratory tract infections, from the common cold to serious illnesses such as Middle East Respiratory Syndrome (MERS) and Severe Acute Respiratory Syndrome (SARS). A new type of corona found in humans since an extraordinary event appeared in Wuhan, China, in December 2019, later named Severe Acute Respiratory Syndrome Coroavirus 2 (SARS-COV2), and caused coronavirus Disease-2019 (Covid-19). The Health Organization (WHO) declared the outbreak to be a publik Health Emergency of International Concern on 30 January 2020 and recognized it as a pandemic on 11 March 2020. ${ }^{45}$ This disease is rarely fatal. Parents and people who have a previous medical history, such as diabetes and antung disease, are more prone to severe conditions if exposed to the corona virus.

A few weeks after it was first known to spread in wuhan, china at the end of December 2019, the Covid-19 epidemic quickly spread and the topic of corona began to be discussed in various media throughout the world. The World Health Organization (WHO) and the governments in each country try their best to reduce transmission rates. Various efforts to prevent the spread of Covid-19 were carried out. Until now, the spread of the corona virus has expanded to more than 200 countries, including Indonesia. The Indonesian government only confirmed the first case of Covid-19 on March 2, 2020. Since then, many policies and strategies have been made in order to prevent the transmission and significant death from this disease. One of them was the issuance of Government Regulation No. 21 of 2020 concerning Large-Scale Social Restrictions in the context of acceleration of the Handling of the 2019 Corona Virus Disease (Covid-19).

The lockdown implementation in several regions in Indonesia is currently aimed at suppressing the spread of Covid-19. By requiring residents of these areas not to recklessly leave the area or their homes are expected to accelerate the completion of the handling of corona virus cases in Indonesia. ${ }^{6}$

4 "Statement on the second meeting of the internatioanal health regulations (2005) Emergency Committee regarding the outbreak of novel coronavirus (2019-nCoV)" World Health Organozation. 30 January 2020. Achived from the original on 31 January 2010. Accessed 8 April 2020.

5 "WHO Director-General opening remarks at the media briefing on COVID-19-11 march 2020" World Health Organization. 11 march 2020. Accessed 8 April 2020.

6 Muhammad Wildan Ramdhani, "Lockdown Policy as a Corona Desease (Covid-19) Management Efforts Asked from the Environmental Aspect of Life Based on Law Act No. 32 of 2009 concerning Protection and Management of Environment", Veteran Law Review,3(1), 2020, pp. 22-36. It also further 
Kumala

With the continued increase in the number of people positive for the outbreak of the COVID-19 virus pandemic, some regional governments have begun to impose Regional Quarantine in their respective regions. Some of them are applied in the Tasikmalaya, Tegal and Ciamis regions. The rest, such as DKI Jakarta, Solo, Bogor, and others plan to also take effect on the Regional Quarantine as well.

1. Tegal, The Mayor of Tegal decided to impose a local lockdown by closing access to Tegal for four months following one of his citizens positively infected with the Corona virus. Some accesses to the city of Tegal will be closed using a water barrier. However, provincial roads and national roads will still be opened. The policy takes effect starting Monday, March 30, 2020. The Mayor of Tegal also said for residents to be able to understand the policy taken and ask their citizens who were migrating to not go home to their hometown during Lebaran this year, and to face the lockdown of the City Government Tegal has prepared a disaster budget of Rp 2 billion. The funds will be used for distribution to the affected poor. ${ }^{7}$

2. Tasikmalaya, The Mayor of Tasikmalaya took steps to close his area or local lockdown as soon as five positive cases of the corona virus appeared in his area. The enactment of the local lockdown began on Tuesday, March 31, 2020. This lockdown decision was taken after there were five people who had tested positive for corona in Tasikmalaya City. This decision includes banning all public transportation or other transportation from outside the area to be prohibited from entering the Tasikmalaya city area. The Mayor of Tasikmalaya also said that his party would establish guard posts at every access to enter the city. The posts will later be filled by a joint team from the TNI, Polri, and local government officials. If there are residents who want to enter for no apparent reason, the joint team will ask him to turn around and prohibit entry. ${ }^{8}$

3. Рариа, The Governor of Papua said access of people and passengers from the sea and air was temporarily closed to curb the spread of the Corona Virus. This is excluded for the transportation of goods and foodstuffs. Papua has closed its main entrance, namely Sentani Airport starting from Thursday, 26 March 2020 until 9 April 2020. In addition, the Emergency Alert Status has been established in Papua from March 17 to April 17, 2020. The policy follows the Papuans

emphasized that, some studies have been confirmed that Lockdown scheme has globally impact in almost all sector in daily life, see also Fadlan Muzakki, "The Global Political Economy Impact of Covid-19 and The Implication To Indonesia", Journal of Social Political Sciences 1(2), 2020, pp.76-92; Wibowo Hadiwardoyo, "Kerugian Ekonomi Nasional Akibat Pandemi Covid-19." BASKARA: Journal of Business \& Entrepreneurship 2(2), 2020, pp. 83-92.

7 Reporting from cnnindonesia.com, Accessed April 102020.

8 Siti Hadijah, "Covid-19 Menyebar di 30 Provinsi, Catat Daerah Ini Terapkan Local Lockdown". (https://www.cermati.com/artikel/covid-19-menyebar-di-30-provinsicatat-daerah-ini-terapkan-local-lockdown). Accessed April 10, 2020 
infected with Covid-19 as of Thursday, March 26, 2020 reaching 7 people. Closing the main entrance to the land of Papua is an important first step as a form of prevention of the spread of the corona virus that has begun to infect Papua. Based on this decision, the Papua regional government has asked the entire community to comply with the call for social restrictions being implemented by the government. ${ }^{9}$

4. Maluku, The Maluku Governor said he would close flight and shipping lines for 14 days. The policy was stated in Governor's Decree number 148 of 2020 concerning Determination of Corona Virus Non-Natural Disaster Emergency Status (Covid-19). The status was set since Sunday, March 22 after residents from Bekasi, West Java, became the first positive Corona patient in Maluku. Temporary closure of sea and air transportation lines does not disrupt the economy in Maluku. In addition, the stock of basic needs for the next five months or during the quarantine period is said to be sufficient to meet the needs of residents in the midst of the corona virus outbreak. ${ }^{10}$

5. Solo, The Mayor of Solo implemented a semi-lockdown by declaring Covid-19 status in Jokowi's hometown as an Extraordinary Event (KLB) based on the results of a coordination meeting on Friday, March 13, 2020. Based on the coordination meeting, the Mayor of Solo decided to implement the area quarantine in part. This decision was applied after there was a positive patient exposed to COVID-19 who died at RSUD dr. Moewardi on Wednesday, March 11, 2020. The semi lockdown decision started from dismissing the school for 14 days and postponing the event that involved many people, canceling the car free day event, to closing the tourist attractions. He said this policy could be extended, adjusting to the conditions and developments in the city of Solo. ${ }^{11}$

6. Bali, Following the Covid-19 case that had arrived in Bali, the provincial government of Bali issued an appeal letter to its citizens to stay in their homes for a day after the Nyepi Day celebration. In letter number 45 / satgascovid19 / III /2020 dated March 23, 2020, issued by considering the increasing cases of corona transmission on the island. I Wayan Koster as the Governor of Bali decided to quarantine the area. Quarantine in Bali is carried out by blocking access routes to several neighboring cities, such as Denpasar. ${ }^{12}$

7. West Sumatera Province, Following the confirmation of 8 positive corona Covid-19 patients in West Sumatra, the local government adopted a policy of tightening inflows across the borders of the local provinces. The policy is called selective restriction, which limits access for people who are unhealthy or are indicated infected with the 


\section{Kumala}

corona virus to enter the area. Following the selective restriction policy, the medical team, Satpol PP, together with the Indonesian National Police will conduct checks on eight West Sumatra border doors.

So, if there are residents who want to enter West Sumatra then it is indicated that a fever will be carried out a health examination at the nearest hospital and considered to carry out quarantine for two weeks. Still have to wait for the central government to do a lockdown in the province of West Sumatra. However, the West Sumatra regional government has begun to build 8 quarantine location points namely: Pasaman Regency, West Pasaman (Pasbar), Dharmasraya, South Coast (Pessel), Sijunjung, Limapuluh Kota, South Solok (Solsel), Minangkabau International Airport (BIM), Padang Pariaman Regency, West Sumatra. ${ }^{13}$

Regional quarantine or Lockdown is the application of quarantine to a certain region or region in order to prevent the movement of people, both in and out of the area, for certain urgent purposes. A regional quarantine policy is established by a country that experiences an emergency such as a war or an outbreak of an infectious disease. This term is widely known due to the 2019 coronavirus or (Covid-19) pandemic which has spread massively in various countries. Some countries that are now implementing territorial quarantine include:

1. Italy, Italy quarantined territories in its country on March 9, 2020. This quarantine had several significant impacts on the country, such as the decline of the Italian economy and the cancellation of sports matches in Italy, including the Serie A soccer league. ${ }^{14}$

2. China (Tiongkok), China closed part of its country, especially Hubei Province on January 23, 2020. It aims to quarantine the coronavirus epicenter which originated from Wuhan city which is the capital of Hubei Province. ${ }^{15}$

3. Spanish, Following Italy's policy of closing the country on March 9, 2020, Spain also implemented a similar policy on March 15, 2020. The policy was intended as one of several emergency measures to combat the coronavirus pandemic in the country. ${ }^{16}$

Currently in Indonesia, regional quarantine is regulated in Law Number 6 Year 2018 regarding Health Quarantine. ${ }^{17}$ In this Law, territorial quarantine is defined as a population restriction in an area

13 Reporting from liputan6.com, Accessed April 10, 2020.

14 "All of Italy is placed under Coronavirus Lockdown". BBC News (in English). 2020-03-10. Accessed April 9, 2020.

15 "Wuhan lockdown 'unprecedented', shows commitment to contain the virus: WHO representative in China". Reuters (in English). 2020-01-23. Accessed April 9, 2020.

16 Jones, Sam (2020-03-14). "Spain orders nationwide lockdown to battle coronavirus". The Guardian (in English). ISSN 0261-3077. Accessed April 92020.

17 The Government of Indonesia (2018). Law Number 6 Year 2018 concerning Health Quarantine. Jakarta: State Secretariat. 
including the entrance area and its contents that are suspected of being infected with disease and / or contaminated in such a way as to prevent possible spread of disease or contamination. The Indonesian central government can establish regional quarantine in response to the WorldAnxious Public Health Emergency.

This step of the Regional Quarantine initiative by some Local Governments can indeed be seen as part of an effort to prevent the spread of the COVID-19 virus. But actually the step actually came out of the standard set out in Law No. 6 of 2018 concerning Health Quarantine (Health Quarantine Act 2018), where to implement Regional Quarantine there should be a prior determination of the status of Public Health Emergency by the Central Government, in which the technical procedures for the enactment of the two matters are regulated further in the Government Regulation implementing regulations on the Quarantine Law Health 2018.

With the issuance of Government Regulation No.21 of 2020 concerning Large-Scale Social Restrictions (Government Regulation of the PSBB) in the Context of Accelerating the Management of Corona Corona Virus Disease (Covid-19) on March 31, 2020. At the same time, the President issued Presidential Decree No. 11 of 2020 concerning Establishment of Covid-19 Public Health Emergency. The publication was based on Law No. 6 of 2018 concerning Health Quarantine which mentions PSBB as part of public health emergency response. The Presidential Decree stipulates Covid-19 as a type of disease that causes public health emergencies, which must be carried out in accordance with statutory provisions. According to the author, with the issuance of the PSBB Government Regulation and Presidential Decree No.11 of 2020 it is appropriate. Because with the issuance of the policy to maintain harmony in handling the Covid-19 outbreak both by the central government and regional governments in order to prevent the spread of Covid-I9 and so that local governments do not make their own policies that are not in line with central government policy.

With the issuance of this policy every Covid-19 countermeasure through the Large-Scale Social Limitation or PSBB, local governments must obtain central government approval. This is in accordance with Article 2 of the Government Regulation on PSBB Large-Scale Social Restrictions which states that local governments can carry out PSBB or limit the activities or movements of people or goods in one particular province or district / city with the approval of the Minister of Health.

Furthermore, Article 5 paragraph (1) of PP 21/2020 states, "In the case of Large-Scale Social Restrictions, it has been determined by the minister who carries out government affairs in the health sector, the Regional Government is obliged to implement and pay attention to the provisions as regulated in Law Number 6 Year 2018 on Qulity Health". Article 5 of Government Regulation No, 21 of 2020 is mandated by Article 49 paragraph (3) of the Health Quarantine Law which states, 
Kumala

"Large-scale Regional Quarantine and Social Restrictions as referred to in paragraph (1) are stipulated by the Minister".

In accordance with Government Regulation No. 21 of 2020, the Large-Scale Social Limitation or PSBB must meet the criteria of the number of cases and / or the number of deaths due to disease increased and spread significantly and quickly to several regions; there are epidemiological links with similar events in other regions or countries. PSBB includes: facilitating schools and workplaces; restrictions on religious activities; and / or restrictions on activities at public places or facilities. Therefore, the regional government has no authority to determine the regional quarantine policy or the PSBB itself. The regional government must coordinate first with the central government so that there is a uniformity of Covid-19 countermeasures. With this PP, not all regions can implement large-scale social restrictions because they have to go through many considerations.

PP No. 21 of 2020 if in relation to the theory of law as an engineering tool as a tool to change or direct the community towards the desired goals, namely to prevent the possibility of spreading Covid-19, and to limit activities considered in the current condition of the covid-19 outbreak. need, creating new patterns and so on. So it can be said, that the legal function as a means or social engineering in its application needs to be done carefully, so that as far as possible does not bring negative impacts as feared, and if necessary in its implementation really will not produce negative impacts. But the most important thing in this connection is the need for all parties related to the application of law in the midst of society, to be truly consistent, both in the sense of honesty, openness, common ground, cooperation and various other effectiveness principles.

Even so there are still unauthorized local governments that set regional quarantine policies or large-scale social restrictions or the PSBB itself. Although the Regional Government may use the reason for discretion as in Law No. 30 of 2014 concerning Government Administration (Government Administration Act 2014), but the policy of the implementation of Regional Quarantine (Local Lockdown) should not necessarily be done without transparency and without careful calculation, which in fact ignores the rights of local citizens who should be able to in a Regional Quarantine situation.

When referring to the provisions of Article 7, Article 8, Article 39, Article 52, Article 55, and Article 79 of the Health Quarantility Act 2018 and Article 8 jo. Article 5 of Law No. 4 of 1984 concerning Infectious Disease Outbreaks (Act of Outbreaks of Infectious Diseases 1984), clearly stated what matters are citizens' rights that must be fulfilled by the Central Government and Regional Governments and related agencies when infectious disease outbreaks occur, emergency situations public health, and are in a situation of Regional Quarantine and Home 
Quarantine as well as in the status of Large-Scale Social Restrictions, which include:

1. The right to get basic health services according to medical needs;

2. The right to get food, and other daily needs;

3. The right to receive the same treatment in administering Health Quarantine;

4. The Government has the right to meet the basic needs for people's lives and animal feed, the implementation of which involves the Central Government, Regional Governments and related parties;

5. For every person who comes from a Public Health Emergency country and / or region, he is entitled to receive services from the Health Quarantine Officer which includes: (1) Screening; (2) Health Alert Card; (3) Information on how to prevent and treat an outbreak; (4) Taking specimens or samples; (5) Referral; and (6) Isolation;

6. The right to receive compensation due to loss of assets caused by the effort to deal with the plague;

7. The right to obtain information on Health Quarantine as an effort to prevent and eradicate the entry and / or exit of events and / or risk factors that can cause a Public Health Emergency.

Referring to the 7 (seven) basic rights of citizens during an outbreak situation, the status of public health emergencies, home quarantine, and regional quarantine, the Central Government and Regional Governments must be ready to take into account the budget allocation of funds to fulfill the basic rights of these citizens.

The government must also prioritize assistance and mitigate disease outbreak prevention, especially to vulnerable groups, especially urban poor who live in densely populated settlements as well as rural poor groups living in rural areas, women, children, homeless people, informal workers, ordinary traders and traders street vendors, disability groups, gender and sexual minority groups, and others, these groups are often neglected and have difficulty gaining access to the rights of their citizens.

The implementation of the Quarantine Area itself can only be made possible as long as the Government has complete consideration materials related to epidemiological aspects, the magnitude of threats, effectiveness, resource support, operational technical, economic, social, cultural, and security considerations. Particularly in the consideration of epidemiological aspects, the Government must have a strong study base related to the correlation between health and disease patterns and related factors at the population level that are potential causes of a COVID-19 pandemic outbreak.

And if want to implement a Large-Scale Social Restriction, referring to the Health Quarantine Act 2018, the enforcement is limited only to; a) school and workplace entertainment; b) restrictions on religious activities; and / or; c) restrictions on activities at public places or facilities. The limitation is carried out solely for the purpose of 
Kumala

preventing the spread of the spread of public health emergencies among people in a certain area. ${ }^{18}$

Disregard for the fulfillment of all the rights of citizens who request the above under any pretext including under the pretext of the status of Civil Emergency status based on Government Substitute Law (Perppu) No. 23 of 1959 concerning Dangerous Conditions, maladministration, and suppressing civil political rights of citizens over severe-, constitutes serious opposition to the mandate of Article $28 \mathrm{H}$ paragraph 1 and Article 34 paragraph 3 of the 1945 Constitution of the Republic of Indonesia, the Health Quarantine Act 2018, the Infectious Disease Act 1984, and the 2014 Government Administration Act.

To carry out regional quarantine needs to consider several things, such as epidemiological considerations, threats, effectiveness, resource support, operational technical, economic, social, cultural, and security.

Article 53 of the Health Quarantine Law explains that the area quarantine is part of the response to public health emergencies. Furthermore, it is regulated regarding the implementation of regional quarantine for all members of the community in an area if the results of laboratory confirmation have spread among community members in that region.

Article 54 states that the Health Quarantine Officer is obliged to provide an explanation to the community in the local area before carrying out the area quarantine. This means that there is an initial socialization before the local lockdown takes place. The quarantined area is quarantined and maintained continuously by the Health and Police Quarantine Officer outside the quarantine area. Quarantine community members may not enter and enter quarantine areas. If during the quarantine period, it turns out that one or several members in the region are suffering from an ongoing Public Health Emergency, an isolation measure is taken and the hospital is immediately referred.

Article 55 states that during quarantine in the area, the basic living needs of people and animal feed in quarantine areas are the responsibility of the central government. The responsibility of the central government in carrying out the area quarantine referred to is carried out by involving the regional government and related parties.

18 For comparison how the law enforcement been implemented in this special situation, please see Adlin, and Ali Yusri. "Penegakan Hukum Pemerintahan: Kekuasaan Walikota Pekanbaru Memberlakukan Beleidsregels Guna Memutus Penyebaran Virus Covid-19 Di Kota Pekanbaru." Jurnal Ilmiah Muqoddimah: Jurnal Ilmu Sosial, Politik dan Hummanioramaniora 4(2), 2020, pp. 71-81. 


\section{THE GOVERMENT CANNOT DO LEGAL ACROBATE IN THE FORMULATION AND ISSUANCE OF COVID-19 OUTPUT RESPONSE POLICY PACKAGING POLICY}

In this case the Government of Indonesia should not carry out arbitrary legal acrobatics in the issuance of implementing regulations rather than a health quarantine policy package to deal with the Covid-19 outbreak. This becomes important, because overcoming the Covid-19 outbreak in addition to requiring good political will from the Government, it also requires adequate legal instruments and implementing regulations that can guarantee transparent governance and also the fulfillment of the right to health of citizens in crisis situations such as this .

As is known the Government has issued 3 (three) legal products regarding the response to the efforts to overcome the Covid-19 plague: (1) Presidential Decree No. RI. 11 of 2020 concerning Establishment of Corona Virus Disease 2019 (COVID-19) Public Health Emergency; (2) Government Regulation No. 21 of 2020 concerning Large-Scale Social Restrictions in Order to Accelerate Handling of Corona Virus Disease 2019 (COVID-19), and; (3) Government Regulation in Lieu of Law (Perppu) No. 1 of 2020 concerning State Financial Policy and Financial System Stability for Handling Corona Virus Disease 2019) COVID-19) and / or In Order to Face Threats that Harm National Economy and / or Financial System Stability.

The issuance of the decision for the determination of the status of public health emergencies by the President of the Republic of Indonesia himself is considered slow to be issued, because of the result of the lags, both the Central Government and Regional Governments experienced stuttering in taking steps to overcome the COVID-19 pandemic outbreak.

The issuance of Government Regulation on Large-Scale Social Restrictions as part of the implementation of Law No. 6 of 2018 concerning Health Quarantine also raises question marks in the community. This is because the Health Quarantine Act itself has clearly stated that there are 4 (four) types of health quarantine actions that can be adjusted to the needs of public health emergencies, which include: 1) Home Quarantine; 2) Hospital Quarantine; 3) Regional Quarantine, and; 4) Large-scale Social Restrictions.

The substance of Government Regulation No. 21 of 2020 is very limited, so it is inadequate to implement the acceleration of handling of COVID 19. This PP only regulates PSBB, and there is no new regulated material, but only records what the Regional Government has done. In fact, to enforce regional quarantine, we need delegation regulations to 
Kumala

provide a basis so that the initiatives of various regional heads in tackling COVID can have clear corridors and basic arrangements.

Regulation of Large-Scale Social Restrictions in Government Regulation No. 21 of 2020 was not done thoroughly, because it only covers the criteria of Large-Scale Social Restrictions (PSBB) and procedures for determining the status by the Minister of Health. The question has not yet been answered about the implementation of Large Scale Social Restrictions (PSBB), especially related to the implementation of the obligations of the state in protecting its citizens. In the regions there was confusion from the provincial level to the village level and each took their own discretion due to legal uncertainty given the practice of Large Scale Social Restrictions (PSBB) running but without the basis of the determination of the Minister of Health. ${ }^{19}$

When referring to the condition of the spread of the COVID-19 virus that occurred in several areas, and the movement of mobility of residents, the thing that should be done is to suppress the spread of the COVID-19 virus by limiting the rate of mobility of citizens to move from one place to another, both residents who are not infected or residents who are infected or at least have had direct contact with people who have contracted the COVID-19 virus.

This means that the policy that can be taken as soon as possible by the Government is the issuance of government regulations governing Home Quarantine, Hospital Quarantine, and Regional Quarantine, to then determine the status of quarantine in accordance with their respective conditions in the field.

Indeed, large-scale social restrictions can also be used to minimize the crowd and social interactions that allow the spread of the COVID-19 virus, but it does not necessarily prevent the rate of mobility of residents in one place to another. This means that it is still possible for the spread of the COVID-19 virus from one region to another.

This kind of legal maneuver is allegedly carried out to avoid the implementation of government obligations towards its citizens, where if the action taken is to determine the status of the Quarantine Area, the Central Government is required to meet and bear the basic needs of its citizens as stated in Article 55 of the Health Quarantine Act. In addition, there is a strong suspicion in the public, that through large-scale social restrictions the Government also wants to determine the status of Civil Emergency afterwards.

19 See also Rahmadya Trias Handayanto, and Herlawati Herlawati. "Efektifitas Pembatasan Sosial Berskala Besar (PSBB) di Kota Bekasi Dalam Mengatasi COVID-19 dengan Model Susceptible-Infected-Recovered (SIR)." Jurnal Kajian Ilmiah 20(2), 2020, pp. 119-124; Aprista Ristyawati, "Efektifitas Kebijakan Pembatasan Sosial Berskala Besar Dalam Masa Pandemi Corona Virus 2019 oleh Pemerintah Sesuai Amanat UUD NRI Tahun 1945." Administrative Law \& Governance Journal 3(2), 2020, pp. 240-249. 
Therefore, the President should immediately revise Government Regulation No. 21 of 2020, with:

1. Adding material that is at least related to the procedure for determining and revoking public health emergencies; as well as the criteria and implementation of Home Quarantine, Regional Quarantine and Hospital Quarantine; and

2. Add material on the mechanism of fulfilling state responsibility towards affected communities in the event of quarantine.

3. Determine the deadline for revision of Government Regulation No. 21 of 2020 to be carried out for no more than 1 week, bearing in mind that this PP is very necessary to implement an accelerated policy of handling COVID 19.

4. In order for the President to order the Minister of Health to immediately establish the status of Large Scale Social Restrictions (PSBB) to be enforced in Indonesia.

\section{THE EFFECTIVENESS OF PSBB POLICY BY THE CENTRAL GOVERNMENT}

April 10, 2020 was the first day of the PSBB policy in Jakarta. ${ }^{20}$ This policy is supported by the Government Regulation (PP) No. 21 of 2020 concerning Large-Scale Social Restrictions in the Context of Accelerating Handling of Corona Virus Disease 2019 (COVID 19), Likewise, the Minister of Health Regulation (Permenkes) No. 9 of 2020. Another regulation relating to the Covid-19 Case is PERPPU No. 1 of 2020 concerning State Financial Policy and Financial System Stability for Handling the 2019 Corona Virus Disease Pandemic and / or in the Context of Facing Threats that Harm National Economy and / or Financial System Stability.

The crucial thing that needs to be examined is the mechanism for implementing Large-scale Social Restrictions (PSBB). The mechanism for determining Large-scale Social Restrictions (PSBB) in a region turned out to require several conditions, where this requirement was alluded to in PP No. 21 of 2018 and confirmed in Minister of Health Regulation No. 9 of 2020. Conditions that must be met by a region to obtain PSBB provisions in accordance with Article 2 of the Minister of Health Regulation No. 9 of 2020, namely an increase in the number of cases, and or the number of deaths significantly in the region, and there are epidemiological links with similar incidents in other regions or countries.

${ }^{0}$ Syamsul Azhar, "The first day of DKI Jakarta PSBB, the number of positive patients 1,810, died 156", accessed from https://regional.kontan.co.id/news/hari-pertamapsbb-dki-jakarta-jotal-pasien-positif -1810-died-156 on April 15, 2020. 
Kumala

Then, the requirement must be submitted by the regional head (governor / regent / mayor) by submitting data on an increase in the number of cases, an increase in the number of spreads over time, as well as the occurrence of local transmissions. The data must then be accompanied by an epidemiological curve that states that transmission has occurred in the region. In addition, in submitting a Large-Scale Social Restrictions (PSBB) request, the regional head needs to convey information about the region's readiness regarding aspects of the availability of people's basic living needs, health infrastructure, the budget and operation of social safety nets, and security aspects.

Then, after the request is submitted, the Minister of Health will form a special team in collaboration with the Corona Virus Handling Task Force, in order to conduct epidemiological studies, taking into account aspects of the readiness of the area. Later, this special team provides recommendations to the Minister of Health to implement the PSBB. But these recommendations can be rejected, or accepted by the Minister of Health. Therefore, there are requirements that tend to be complicated for determining the status of Large-Scale Social Restrictions (PSBB) in an area based on Permenkes No. 9 of 2020, it needs to be questioned. Why? Because of the many requirements that must be met by the Regional Government it is feared that it will hamper the process of handling Covid-19.

The next regulation that needs to be examined is Government Regulation No. 21 of 2020. PP No. 21 of 2020 is a form of rules delegated by Law no. 6 of 2018, precisely in Article 10 paragraph 4. With this, the nature of Government Regulation No. 21 of 2020 acts as an implementing regulation related to all policies that will be implemented, in order to implement Large-Scale Social Restrictions. But if we look further into Article 4 PP No. 21 of 2018, it was explained that: Article 4 paragraph: 1). Large-scale social restrictions include at least school and workplace entertainment, restrictions on religious activities, and / or restrictions on activities in public places or facilities. 2). The limitation of activities as referred to in paragraph (1) letter a and letter b must still consider the educational needs, work productivity, and worship of the population. 3). The limitation of activities as referred to in paragraph (1) letter $\mathrm{c}$ shall be carried out by taking into account the fulfillment of the basic needs of the population.

The sentence in Article 54 paragraph (1) is exactly the same as in Article 59 of Law No. 6 of 2018. In fact, government regulations have a role to explain the implementation of the rules of the law that delegate them. However, this has not been seen in PP No. 21 of 2020, precisely in Article 4 paragraph (1) explains the existence of consolation in the context of anticipating the transmission of Covid-19, when in fact the school or workplace is not closed, but learning from a distance for schools, and for some workplaces impose work from home (WFH). Therefore, this provision is not appropriate, although in paragraph (2) 
there is further information related to Article 4 paragraph (1). However, still the provisions in paragraphs (2) and (3) do not contain practical mechanisms regarding the implementation of Article 4 paragraph (1).

This shows the use of diction in legal instruments is so important, especially in the use of the word "vacation" for workers. Because, this will have implications for the provision of salary or wages which is a right for workers after doing a job. Meanwhile, when employees are off there is no salary or wages. So, the explanation of the clause in a regulation must be as clear as possible. However, the clarity in clause in PP No. 21 of 2020 has not been achieved. Besides that, things that need to be observed in Permenkes No. 9 of 2020 and in PP No. 21 of 2020. As implementing regulations, the two regulations do not yet include PSBB operational provisions. For example, the implementation of PSBB by those who must meet their daily needs by working outside the home and activities outside the home are classified as exceptions. With this, the two regulations are still too simple for an implementing regulation.

Then, what needs to be examined next is PERPPU No. 1 of 2020. Where PERPPU has the intention to become the legal basis, with the enactment of the state budget reallocation, along with the Covid-19 case. However, in the substance of this PERPPU there are articles which are quite controversial, namely Article 27 which states that officials of the Financial System Stability Committee (KSSK), the Ministry of Finance, Bank Indonesia (BI) Financial Services Authority (OJK), the Deposit Insurance Agency (LPS), so that other officials cannot be prosecuted criminal or civil as long as they carry out their duties in good faith and in accordance with the provisions. The article indirectly explains the immunity possessed by officials so that it cannot be prosecuted if there is a loss suffered by the state due to this case.

Realization of the PSBB policy to date has been officially carried out by the DKI Jakarta Provincial Government. ${ }^{21}$ The implementation of PSBB in Jakarta is accompanied by the Governor of Jakarta Special Capital Region Regulation Number 33 of 2020, as the mechanism for implementing PSBB in Jakarta. As stated by the Governor of DKI Jakarta, Anies Baswedan that in essence all policies contained in the DKI Governor Regulation No. 33 of 2020 includes all restrictions on activities outside the home as has been urged by the Government. ${ }^{22}$ The difference is, there are sanctions for those who release the PSBB in Article 27 of the DKI Governor Regulation No. 30, which refers to Article 93 of Law No.

21 Monica Wareza, Issuer Starts Affected Covid-19 \& Tomorrow Jakarta Starts PSBB, accessed via https://www.cnbcindonesia.com/market/20200409075153-17150755/emiten-mulai-terdampak-covid-19-besok-jakarta-mulai- psbb on April 15, 2020.

22 Vitorio Mantalean, and Egidius Patnistik, "Detailed Rules for PSBB in Jakarta are estimated to be Ready Tomorrow", accessed via https://megapolitan.kompas.com/read/2020/04/07/21580901/aturan-rinci-psbb-dijakarta- estimated-ready-tomorrow on April 15, 2020. 
Kumala

6 of 2018 namely, the sanction in the form of a maximum of one year imprisonment and / or a maximum fine of one hundred million rupiah.

Meanwhile, the Riau provincial government admitted that it had experienced problems in establishing the PSBB, due to the continued increase in the number of returning migrant workers, so that this led to continued changes in the data collection. ${ }^{23}$ The Tangerang region is still reviewing the PSBB system and has not proposed it to the Ministry of Health. Arief Wismansyah, Mayor of Tangerang City claimed he would monitor Jakarta first in the implementation of the PSBB. ${ }^{24}$ Therefore, the statement of the three regions shows that the implementation of PSBB has not been implemented evenly in all regions, this is something that is reasonable, given the complicated conditions that need to be met by each region in the implementation of the PSBB. The next policy realization is related to social assistance provided to the lower strata of society. At the press conference, President Jokowi announced that social assistance would be carried out in various forms, such as food, direct cash assistance, free and discounted electricity costs by certain groups, training of bus drivers, taxis, and trucks, as well as reducing credit payments aimed at to UMKM and online motorcycle taxis. ${ }^{25}$

However, at the next press conference there were still a number of questions represented by the public that there were still online ojegs who claimed to be still being chased by loan sharks. But the OJK claimed to have responded to this by organizing cooperation with an online motorcycle taxi company that employs the motorcycle taxi driver concerned, so that the company can take part in organizing this assistance. ${ }^{26}$

Furthermore, assistance regarding some basic food was handed over by President Jokowi to the online motorcycle taxi drivers. ${ }^{27}$ However, the distribution of food is not yet certain to be part of the social

23 Media Indonesia, "PSBB in Riau Hampered TKI Flow from Malaysia", accessed via https://mediaindonesia.com / read / detail / 302473-psbb-di-riau-blocked-tkifrom-malaysia at taggal April 15, 2020.

24 I Gusti Agung Bagus Angga Putra, "Mayor of Tangerang, PSBB Must Be Simultaneously All Over Greater Tangerang", accessed via https://bebas.kompas.id/baca/metro/2020/04/07/wali-kota- tangerang-psbb-mustsimultaneously-tangerang-raya / on 15 April 2020.

25 Chandra Gian Asmara, "Take notes! These are BLT and Sembako which want to be spread by Jokowi ", accessed via https://www.cnbcindonesia.com/news/20200409162618-4-150957/catat-ini-bltdan-sembako-yang-mau-disebar-jokowi on the 15th April 2020.

26 Fika Nurul Ulya, and Yoga Sukmana, "Ojol Driver Viral Still Chased by Debt Collector, This is OJK Said", accessed via https://money.kompas.com/read/2020/04/06/134825526/viral-peng Driving -ojolstill-being chased-debt-collector-this-word-ojk? page = all on 15 April 2020.

27 CNN Indonesia, "Jokowi Distributes Groceries to Online Drivers on the Side of the Road", accessed via https://www.cnnindonesia.com/nasional/20200409183246-20492231/jokowi-breading-sembako-ke-peng Driving-ojol- on the side of the road on April 15, 2020. 
assistance provided by the State, or from President Jokowi in person. Because the delivery of basic food items as state aid, should be promoted by each Regional Government with their respective regional budgets, and information on this matter has not yet developed. An equally important aid is direct cash assistance, which is one of the hopes of the grassroots to meet their daily needs, because since the Covid-19 case many small communities have experienced significant income reductions. Especially related to the PSBB policy in DKI Jakarta, which explicitly prohibits online motorbike taxi to carry passengers. In addition to the reduction in daily income felt by motorcycle taxi drivers, it was also felt by those who worked within the UMKM, taxi drivers, public transportation drivers, and those whose income was only fulfilling their daily needs.

Therefore, cash aid needs to be realized to those who really need it. However, again there are still sad events as a result of the Covid-19 case, namely the existence of online motorcycle taxi drivers and families who were kicked out of their renters because they have not paid rent. ${ }^{28}$ The motorcycle taxi driver admitted that since the Covid-19 case was found it was very difficult to get income. ${ }^{29}$ Then, this causes him unable to pay rent. When interviewed by reporters at one television station, the driver claimed not to get any help from the government. Thus, this shows that direct cash assistance has not yet run, or it could have been running, but it is still not evenly distributed and on target.

By looking at the statement above, the PSBB policy chosen by the government in response to the Covid-19 pandemic is still in the process of being implemented. Although it has not been done thoroughly, but at least there have been developments made by several regions. However, there are still areas that are still reviewing the policy. Likewise with the social assistance policy that was initiated by President Jokowi, it is still in the process of maximizing, although there are still some obstacles in its implementation.

\section{CONCLUSION}

The case of Covid-19, which is a global pandemic clearly raises concerns from various groups, especially the public. The concern of the community is getting worse by seeing a surge in cases that are fast enough, as well as seeing the lack of readiness of several areas that are vital enough to "fight" the corona virus. So with that, the public demanded that the government be able to provide protection, in

28 Bonfillio Mahendra Wahanputra Ladjar, and Sabrina Asil, "The Story of Dodo, Online Ojek Drivers Evicted from Rented and Sleeping on the outskirts of Ruko" accessed via https://megapolitan.kompas.com/read/2020/04/08/18100551/ storydodo-ojek-motorcycle-driver-online-expelled-from-rent-and-sleep-on? page $=3$ on 15 April 2020.

29 Ibid. 
Kumala

accordance with the mandate of the 1945 Constitution. One form of protection that can be given by the Central Government and Regional Governments, namely, is a policy to address the Covid-19 case.

However, policies issued by the central and regional sectors often experience "overlapping" or in other words, different. This is seen because of the lack of clear coordination between the Regional Government and the Central Government. On the other hand, the Regional Government is a public official who is closest to the people in his area, so that the Regional Government knows more about the needs and characteristics of the region. However, on the other hand there are rules in Law No. 6 of 2018 implies that the central government has the authority to issue a health emergency policy. Therefore, this resulted in the application of policies to address the existence of Covid-19 to be quite complicated. Even though the case currently being faced by the community is a virus that has claimed many lives.

However, the complexity was quite distinguished by the existence of a firm statement from President Jokowi regarding the largescale Social Limitation policy he chose. However, by looking at the process of establishing PSBB in an area, it is feared that the PSBB will only become a piece of policy, without uniform implementation in all regions. If this happens, it will cause a very fatal impact which is the impact on the Government's slow handling of the Covid-19 case. In addition, the legal instruments that were issued in line with the implementation of the PSBB have not shed any light on the question marks created by the current conditions experienced by the community. Like other policies related to the implementation of PSBB operations by various groups and community rights as long as the PSBB has not been included in the legal instrument. Likewise, the realization of policies that until now have not been running uniformly related to the PSBB, even social assistance that has not been received directly by the community. So, we need to guide, control and monitor together related to the implementation process of the policies that have been issued by the Government. Because, the best possible regulation is a regulation that is realized.

\section{REFERENCES}

Adlin, A., \& Yusri, A. (2020). Penegakan Hukum Pemerintahan: Kekuasaan Walikota Pekanbaru Memberlakukan Beleidsregels Guna Memutus Penyebaran Virus Covid-19 di Kota Pekanbaru. Jurnal Ilmiah Muqoddimah: Jurnal Ilmu Sosial, Politik dan Hummanioramaniora, 4(2), 71-81.

Asmara, C. G. (2002). "Take notes! These are BLT and Sembako which want to be spread by Jokowi", CNBC Indonesia, retrieved from https://www.cnbcindonesia.com/news/20200409162618-4- 
150957/catat-ini-blt-dan-sembako-yang-mau-disebar-jokowi accessed on 15th April 2020.

Azhar, S. (2020). "The first day of DKI Jakarta PSBB, the number of positive patients 1,810, died 156", KONTAN News, retrieved from from https://regional.kontan.co.id/news/hari-pertama-psbb-dkijakarta-jotal-pasien-positif -1810-died-156 on April 15, 2020.

Hadijah, S. (2020). "Covid-19 Menyebar di 30 Provinsi, Catat Daerah Ini Terapkan Local Lockdown". Online Article, retrieved from https://www.cermati.com/artikel/covid-19-menyebar-di-30provinsi-catat-daerah-ini-terapkan-local-lockdown. Accessed April 10, 2020.

Hadiwardoyo, W. (2020). Kerugian Ekonomi Nasional Akibat Pandemi Covid-19. BASKARA: Journal of Business \& Entrepreneurship, 2(2), 83-92.

Handayanto, R. T., \& Herlawati, H. (2020). Efektifitas Pembatasan Sosial Berskala Besar (PSBB) di Kota Bekasi Dalam Mengatasi COVID-19 dengan Model Susceptible-Infected-Recovered (SIR). Jurnal Kajian Ilmiah, 20(2), 119-124.

Jones, S. (2020). "Spain orders nationwide lockdown to battle coronavirus". THE GUARDIAN. ISSN 0261-3077. Accessed April 92020.

Ladjar, B. M. W., \& Asil, S. (2020). "The Story of Dodo, Online Ojek Drivers Evicted from Rented and Sleeping on the outskirts of Ruko", KOMPAS, retrieved from https://megapolitan.kompas.com/read/2020/04/08/18100551/ story-dodo-ojek-motorcycle-driver-online-expelled-from-rentand-sleep-on? page $=3$, accessed on 15 April 2020 .

Muzakki, F. (2020). The Global Political Economy Impact of Covid-19 and The Implication to Indonesia. Journal of Social Political Sciences, 1(2), 76-92.

Pranita, E. (2020). "Berbagai Respon Rakyat Untuk Pemerintah Terkait Penanganan Covid-19", KOMPAS, https://www.kompas.com/sains/read/2020/04/02/100200323/berb agai-respons-rakyat-untuk-pemerintah-terkait-penanganan-covid19, Accessed 8 April 2020.

Putra, I. G. B. A. (2020). "Mayor of Tangerang, PSBB Must Be Simultaneously All Over Greater Tangerang", KOMPAS, retrieved from https://bebas.kompas.id/baca/metro/2020/04/07/wali-kotatangerang-psbb-must-simultaneously-tangerang-raya/, accessed on 15 April 2020.

Ramdhani, M. W. (2020). Lockdown Policy as a Corona Desease (Covid19) Management Efforts Asked from the Environmental Aspect of Life Based on Law Act No. 32 of 2009 concerning Protection and Management of Environment. Veteran Law Review, 3(1), 22-36.

Ristyawati, A. (2020). Efektifitas Kebijakan Pembatasan Sosial Berskala Besar Dalam Masa Pandemi Corona Virus 2019 oleh Pemerintah 
Kumala

Sesuai Amanat UUD NRI Tahun 1945. Administrative Law \& Governance Journal, 3(2), 240-249.

Republic of Indonesia (2018). Law Number 6 of 2018 concerning Health Quarantine [Undang-Undang Nomor 6 Tahun 2018 tentang Karantina Kesehatan].

Ulya, F. N., \& Sukmana, Y. (2020). "Ojol Driver Viral Still Chased by Debt Collector, this is OJK Said", KOMPAS, retrieved from https://money.kompas.com/read/2020/04/06/134825526/viral-

peng Driving -ojol-still-being chased-debt-collector-this-wordojk? page $=$ all on 15 April 2020 .

[...] "First coronavirus cases confirmed in Indonesia amid fears nation is ill-prepared for an outbreak", THE GUARDIAN. 8 March 2020. Accessed 8 April 2020.

[...] "Indonesia confirms first cases of coronavirus". BANGKOK POST, retrieved from www.bangkokpost.com. Accessed 8 April 2020

[...] "Statement on the second meeting of the internatioanal health regulations (2005) Emergency Committee regarding the outbreak of novel coronavirus (2019-nCoV)" World Health Organozation. 30 January 2020. Achived from the original on 31 January 2010. Accessed 8 April 2020.

[...] "WHO Director-General opening remarks at the media briefing on COVID-19-11 march 2020" World Health Organization. 11 march 2020. Accessed 8 April 2020.

[...] Reporting from cnnindonesia.com, Accessed April 102020.

[...] Reporting from liputan6.com, Accessed April 10, 2020.

[...] "All of Italy is placed under Coronavirus Lockdown". BBC News, 2020-03-10. Accessed April 9, 2020.

[...] "Wuhan lockdown 'unprecedented', shows commitment to contain the virus: WHO representative in China". Reuters, 2020-01-23. Accessed April 9, 2020.

[...] "PSBB in Riau Hampered TKI Flow from Malaysia", Media Indonesia, retrieved from https://mediaindonesia.com/read /detail/302473-psbb-di-riau-blocked-tki-from-malaysia, accessed on April 15, 2020.

[...] "Jokowi Distributes Groceries to Online Drivers on the Side of the Road", CNN Indonesia, retrieved from https://www.cnnindonesia.com/nasional/20200409183246-20492231/jokowi-breading-sembako-ke-peng Driving-ojol- on the side of the road on April 15, 2020. 